УДК 519.21

DOI: 10.30838/J.PMHTM.2413.241219.47.600

\title{
WAYS OF REGULARIZATION OF MATERIALS SCIENCE ILL-POSED PROBLEMS
}

\author{
DUBROV Yu.I. ${ }^{1}$, Dr. Sc. (Tech.), Prof., \\ VOLCHUK V.M. ${ }^{2 *}$, Dr. Sc. (Tech.), Ass. Prof.
}

${ }^{1}$ Department of Materials Science, State Higher Educational Institution "Prydniprovska State Academy of Civil Engineering and Architecture", 24-a, Chernyshevskoho St., 49600, Dnipro, Ukraine, tel. +38 (0562) 47-39-56, e-mail: mom@mail.pgasa.dp.ua, ORCID ID: 0000-0002-3213-4893

$2^{2}$ Department of Materials Science, State Higher Educational Institution "Prydniprovska State Academy of Civil Engineering and Architecture", 24-a, Chernyshevskoho St., 49600, Dnipro, Ukraine, tel. +38 (0562) 47-39-56, e-mail: volchuky@, gmail.com, ORCID ID: 0000-0001-7199-192X

\begin{abstract}
Introduction. The ill-posedness of the problems is mainly caused by the incompleteness of their formal axiomatics, which is a consequence of the incompleteness of our knowledge of the object of identification. This fact demonstrates the formal axiomatic incompleteness, arising in description of the metal structure elements by means of traditional configurations of Euclidean geometry, which triggers the need to use other promising approaches to the structure assessment. The aim of the work is to establish solutions to some conditionally incorrect materials science problems. Statement of basic materials. On the basis of the analysis of quantitative and qualitative assessment of the real structures of many iron carbon alloys, there are observed some significant, for practical purposes, divergences between results of direct experiments and results of their prediction. Basic ways of regularization of identification problems of multi-parameter objects, criteria selection for multi-criteria technology optimization, ranging of multiparameter technologies quality criteria, material quality estimation are considered. It is shown that regularization of materials science conditionally ill-posed problems is acceptable with application of specific algorithms for every specific case. Conclusions. It is shown that some of the conditionally incorrect problems are solved by applying a language of a higher level - the language of fractal geometry.
\end{abstract}

Keywords: ill-posed problems; multiparametric technology; the area of self-similarity; materials; the regularization

\section{ШЛЯХИ РЕГУЛЯРИЗАЦІЇ НЕКОРЕКТНИХ ЗАДАЧ МАТЕРІАЛОЗНАВСТВА}

\author{
ДУБРОВ Ю. І. ${ }^{1}$, д. m. н., проф., \\ ВОЛЧУК В. Н. ${ }^{2^{*}}$, д. m. н., доu.
}

1 Кафедра матеріалознавства та обробки матеріалів, Державний вищий навчальний заклад "Придніпровська державна академія будівництва та архітектури", вул. Чернишевського, 24-а, 49600, Дніпро, Україна, тел. +38 (0562) 47-39-56, e-mail: mom@mail.pgasa.dp.ua, ORCID ID: 0000-0002-3213-4893

$2^{*}$ Кафедра матеріалознавства та обробки матеріалів, Державний вищий навчальний заклад "Придніпровська державна академія будівництва та архітектури", вул. Чернишевського, 24-а, 49600, Дніпро, Україна, тел. +38 (0562) 47-39-56, e-mail: volchuky@,gmail.com, ORCID ID: 0000-0001-7199-192X

Анотація. Bcmyn. Некоректність задач, в основному, обумовлена неповнотою їх формальної аксіоматики, що є наслідком неповноти наших знань про об'єкт ідентифікації. Даний факт свідчить про неповноту формальної аксіоматики, яка виникає при описі елементів структури металу за допомогою традиційних фігур геометрії Евкліда, що ініціює необхідність використання інших, перспективних підходів до оцінки структури. Метою роботи є встановлення рішень деяких умовно некоректних задач матеріалознавства. Виклад основного матеріалу. На підставі аналізу кількісної та якісної оцінки реальних структур багатьох залізовуглецевих сплавів спостерігаються деякі значні, для використання в практичних цілях, розбіжності між результатами прямих експериментів, і результатами їх прогнозування. Розглянуто основні способи регуляризації задач ідентифікації багатопараметричних об'єктів, вибору критеріїв оптимізації багатокритеріальних технологій, ранжирування критеріїв якості багатопараметричних технологій, оцінки якості матеріалів. Показано, що регуляризація умовно некоректних задач в матеріалознавстві прийнятна із застосуванням конкретних алгоритмів для кожного конкретного випадку. Висновки. Показано, що деяка частина умовно некоректних задач вирішується шляхом застосування мови вищого рівня - мови фрактальної геометрії.

Ключові слова: некоректні задачі; багатопараметрична технологія; область самоподібності; матеріали; регуляризація 


\section{ПУТИ РЕГУЛЯРИЗАЦИИ НЕКОРРЕКТНЫХ ЗАДАЧ МАТЕРИАЛОВЕДЕНИЯ}

ДУБРОВ Ю. И. ${ }^{1}$, д. т. н., проф., ВОЛЧУК В. Н. ${ }^{2^{*}}$, д. m. н., доч̧.

${ }^{1}$ Кафедра материаловедения и обработки материалов, Государственное высшее учебное заведение "Приднипровская государственная академия строительства и архитектуры", ул. Чернышевского, 24-a, 49600, Днипро, Украина, тел. +38 (0562) 47-39-56, e-mail: mom@mail.pgasa.dp.ua, ORCID ID: 0000-0002-3213-4893

$2^{*}$ Кафедра материаловедения и обработки материалов, Государственное высшее учебное заведение "Приднипровская государственная академия строительства и архитектуры", ул. Чернышевского, 24-a, 49600, Днипро, Украина, тел. +38 (0562) 47-39-56, e-mail: volchuky@gmail.com, ORCID ID: 0000-0001-7199-192X

Аннотация. Введение. Некорректность задач, в основном, обусловлена неполнотой их формальной аксиоматики, являющейся следствием неполноты наших знаний об объекте идентификации. Данный факт свидетельствует о неполноте формальной аксиоматики, которая возникает при описании элементов структуры металла с помощью традиционных фигур геометрии Евклида, что инициирует необходимость использования других, перспективных подходов к оценке структуры. Целью работы является установление решений некоторых условно некорректных задач материаловедения. Изложение основного материала. На основании анализа количественной и качественной оценки реальных структур многих железоуглеродистых сплавов наблюдаются некоторые значительные, для использования в практических целях, расхождения между результатами прямых экспериментов, и результатами их прогнозирования. Рассмотрены основные способы регуляризации задач идентификации многопараметрических объектов, выбора критериев оптимизации многокритериальных технологий, ранжирования критериев качества многопараметрических технологий, оценки качества материалов. Показано, что регуляризация условно некорректных задач в материаловедении приемлема с применением конкретных алгоритмов для каждого конкретного случая. Bыводы. Показано, что некоторая часть условно некорректных задач решается путем применения языка более высокого уровня - языка фрактальной геометрии.

Ключевые слова: некорректные задачи; многопараметрическая технология; область самоподобия; материалы; регуляризация

\section{Introduction}

The setting of ill-posed problems, as a rule, is formulated taking into account the mutual influences of all elements of their components, which initiates the need to describe these interactions at micro- and macrolevels. Hereafter, such problems became widespread in statistics, logic, economics and human relationships and this fact is confirmed by the spectrum of topics listed in them. It should be noted that the problem is ill-posed in the following circumstances: the problem includes more than one solution; the problem has unstable solution (in the sense that the solutions may differ widely with a relatively small change in the initial data) [1].

\section{Statement of basic materials}

The ill-posedness of the problems is mainly caused by the incompleteness of their formal axiomatics [2], which is a consequence of the incompleteness of our knowledge of the object of identification [3].

According to the principle of "external additions" of Stafford Beer [4], incompleteness of formal axiomatics may by partly compensated by application of higherlevel language than those at which the problem was stated. For example, fractal geometry language $[5 ; 6]$ allows estimating objects structure more strictly in comparison with integral-valued Euclidean geometry. At the same time, the information on interatomic and intermolecular interactions is not enough for an adequate description of the materials, and this obliges the researcher to apply statistical methods with correction factors.
In materials science, to study the structure and properties of metals and alloys, there are applied the traditional methods of X-ray analysis, optical and electron microscopy, thermal analysis, electron microprobe sounding, nuclear magnetic resonance, Auger spectroscopy, etc. Interconnections of the metal structure parameters and the complex of their physical and mechanical properties are considered in a large number of works (see, for example, [7-9]), where, in particular, in the paper [10] it is noted that I.V. Tananayev, developing N.S. Kurnakov's concepts of phase-rule diagrams and diagrams of «composition property», remarked that it is necessary to replace the triad («composition - structure - properties») with a quadriga including another structural characteristics and dispersion of the structure components. This approach makes it possible to take into account the impact of the metal structure elements on the metal properties. However, the difficulty lies in the fact that many elements of the metal structure, owing to the complicated configuration, do not readily lend themselves to the quantitative description, which leads to loss of important information about the tandem of structure - properties. Such characteristics can include the currently existing assessment of the metal microstructure elements by means of regulatory documents using mainly the appraisal by points. The subjectivity in estimating the metal structure parameters is observed, for example, when numerically assessing the flake vermicular graphite, ledeburite eutectic, acicular ferrite, martensite needles, Widmanstatten ferrite, upper and lower bainite, troostite, grain boundaries, etc., which is explained by 
the complex configuration of their shape. To identify such structures, there is probably a need of introducing a new quantitative index.

Difficulties in the metal structure assessment initiate the search of new assessment approaches in order to determine the spectrum of the metal mechanical properties. It is referred to properties that would ensure, at the lowest possible cost, the required accuracy of the research results.

Materials science ill-posed problems mainly include problems in which the following is considered:

- Influence of various damages of the materials structure.

- Influence of the material composition.

- Influence of technological factors (conditions of product manufacture, processing type as well as conditions of operation environment and etc.).

- Structural stability of material (retention of material structure within the prescribed limits on exposure to different factors).

- Receipt of new materials.

In order to avoid unnecessary randomness in presenting the purpose of this paper we exclude the cumbersome formalization of each particular problem, which can be found in the indicated primary literature published in the leading newspapers, which makes the description of the method of its regularization more adequate.

Depending on stated goals, materials science problems divide into ill-posed and conditionally ill-posed problems. Ill-posed problems include those ones which do not have a solution. Conditionally ill-posed problems of materials science include those ones which have a solution in the defined areas. The last is feasible through regularization which involves addition of useful information to the specified conditions.

The following is considered as an example of materials science conditionally ill-posed problems:

1. Regularization of identification problem of multiparameter object $[11 ; 12]$.

2. Regularization of problem of criterion selection for multi-criteria technology optimization $[13 ; 14]$.

3. Regularization of problem of multi-parameter technologies quality criteria ranging [15].

4. Regularization of problem of metal quality characteristics estimation $[16 ; 17]$.

5. Regularization of problem of the object model selection $[18 ; 19]$.

6. Regularization of nanotechnology model selection [20].

According to the first paragraph, model of the selfsimilarity area key parameter is suggested as an operator to regularize a multi-parameter object; this parameter is a function of temperature, pressure, cooling agent consumption and capacity. This regularization allows reducing probability of occurrence of abnormal situation, as key parameter nears one of the boundaries of the selfsimilarity area.

In the second paragraph regularization is shown using the manufacturing technology of cast iron rolls. The following algorithm is suggested as a regularizing operator: a) determination of effective range of technology parameters in compliance with the regulatory documents $b$ ) determination of effective range section with suboptimal properties c) determination of compromise criterion with minimally contradictory product quality indexes.

In paragraph 3 problem of multiparameter technologies quality criteria ranging is regularized through comparison of values of the self-similarity area.

In paragraph 4 regularization of problem of metal quality estimation is implemented through creation of operator of metal mechanical properties.

In paragraph 5 regularization of problem of object selection is implemented through application of the operator which includes the following algorithm:

- Selection and validation of key parameter.

- Validation of belonging of the identification object to a particular type and class.

- Determination of self-similarity boundaries of the identification object.

Interpretation of results obtained during modeling process.

Taking into consideration the promising area of modern materials science that includes nanotechnologies the solution of these problems is characterized by a conditional ill-posedness, which is caused by physical regularities based on the description of interaction processes based, in particular, on fractal formalism.

In connection therewith, in paragraph 6 , the possible operators are nanomaterials with specified functions when using viruses, in which their surfaces represent special tools for passing of biological barriers. Moreover, the viruses are under study as a as samples for molecular electronics modeling [20].

The change in the parameter range of each conditional ill-posed subproblem is set taking into account the acceptable quantifiable presentational values.

\section{Conclusions}

The paper shows that variety of materials science conditional ill-posed problems initiates the variety of individualized methods of regularization that performs the complexity and necessity of their reasonable scientific realization.

\section{REFERENCES}

1. Tikhonov A.N., Arsenin V.Yu. Solutions of Ill-Posed Problems. New York : Winston, 1977, 258 p.

2. Gödel K. Über formal unentscheidbare Sätze der Principia Mathematica und verwandter Systeme I. Monatshefte für Mathematik und Physik, 1931, vol. 38, no. 1, pp. 173-198. (in Germany). 
3. Bolshakov Vad.I., Bolshakov V.I., Volchuk V.N. and Dubrov Yu.I. Chastkova kompensatsiya nepovnoty formal'noyi aksiomatyky pry identyfikatsiyi struktury metalu [The partial compensation of incompleteness of formal axiomatics in the identification of the metal structure]. Visnyk akademiyi nauk Ukrayiny [Bulletin of the National Academy of Sciences of Ukraine]. 2014, no. 12, pp. 45-48. (in Ukrainian). - Available at: http://dspace.nbuv.gov.ua/handle/123456789/73434

4. Bir S. Kibernetika $i$ upravleniye proizvodstvom [Cybernetics and production management]. Moscow: Nauka, 1963,276 p. (in Russian).

5. Mandelbrot B.B. The Fractal Geometry of Nature : monograph. New-York, San Francisco: Freeman, 1982, 480 p. - Available at: http://www.amazon.com/Fractal-Geometry-Nature-Benoit-Mandelbrot/dp/0716711869

6. Volchuk V., Klymenko I., Kroviakov S. and Orešković M. Method of material quality estimation with usage of multifractal formalism. Tehnički glasnik - Technical Journal, 2018, vol. 12, no. 2, pp. 93-97. - Available at: https://doi.org/10.31803/tg20180302115027

7. Calcagni G., Giuseppe Nardelli G. and Rodríguez-Fernández D. Particle-physics constraints on multifractal spacetimes. Physical Review D. 2016, vol. 93, no. 2, pp. 025005. - Available at: https://doi.org/10.1103/PhysRevD.93.025005

8. Zhuravel' I.M. Computer Analysis of the Distribution of Grain Sizes in the Structure of 12Kh1MF Steel After Operation. Materials Science. 2019, vol. 55, no 2, pp. 187-192.

9. Mishutin A.V., Kroviakov S.O., Mishutin N.V. and Bogutsky V.L. Modified expanded clay lightweight concretes for thinwalled floating structures. Proceeding of the Second International Conference on Concrete Sustainability (ICCS16). Madrid, Spain on 13-15 June, 2016. - Barcelona, Spain: International Center for Numerical Method in Engineering, 2016, pp. 743-749.

10. Ivanova V.S., Balankin A.S., Bunin I.Zh. and Oksogoev A.A. Sinergetika i fraktaly v materialovedenii [Synergetics and fractals in materials science]. Moscow : Nauka, 1994, 383 p. (in Russian).

11. Dubrov Yu., Bolshakov V. and Volchuk V. Puti identifikatsii periodicheskikh mnogokriterial'nykh tekhnologiy [Road periodic identification of multi-criteria Technology]. Saarbrucken : Palmarium Academic Publishing, 2015, 236 p. (in Russian).

12. Bolshakov V.I., Volchuk V.N. and Dubrov Yu.I. O prognozirovanii kachestva tselevogo produkta $v$ periodicheskikh tekhnologiyakh [Predicting the quality of a desired product in periodic technologies]. Dopovidi Natsionalnoi akademii nauk Ukrainy [Reports of the National Academy of Sciences of Ukraine]. 2014, no. 11, pp. 77-81. (in Russian). - Available at: https://doi.org/10.15407/dopovidi2014.11.077

13. Bolshakov V.I., Volchuk V.N. and Dubrov Yu.I. Etapy identyfikatsiyi bahatoparametrychnykh tekhnolohiy ta shlyakhy yikh realizatsiyi [Stages multiparameter identification technologies and ways of their implementation]. Visnyk Natsional'noyi akademiyi nauk Ukrayiny [Bulletin of the National Academy of Sciences of Ukraine]. 2013, no. 8, pp. 66-72. (in Ukrainian). - Available at: http://www.visnyk-nanu.org.ua/uk/node/814

14. Bolshakov V.I., Volchuk V.M. and Dubrov Yu.I. Regularization of One Conditionally Ill-Posed Problem of Extractive Metallurgy. Metallofizika i Noveishie Tekhnologii, 2018, vol. 40, no. 9, pp. 1165-1171. - Available at: DOI: $10.15407 /$ mfint.40.09.1165

15. Volchuk V.M. K primeneniyu fraktal'nogo formalizma pri ranzhirovanii kriteriyev kachestva mnogoparametricheskikh tekhnologiy [On the Application of Fractal Formalism for Ranging Criteria of Quality of Multiparametric Technologies]. Metallofizika I noveyshiye tekhnologii [Metal Physics and Advanced Technologies]. 2017, vol. 39, no 3, pp. 949-957. (in Russian). Available at: https://doi.org/10.15407/mfint.39.07.0949

16. Kroviakov S., Zavoloka M., Dudnik L. and Kryzhanovskyi V. Comparison of strength and durability of concretes made with sulfate-resistant portland cement and portland cement with pozzolana additive. Electronic Journal of the Faculty of Civil Engineering Osijek-e-GFOS, 2019, vol. 10, no. 19, pp. 81-86. - Available at: https://doi.org/10.13167/2019.19.8

17. Bolshakov V.I. and Volchuk V.N. Materialovedcheskiye aspekty primeneniya veyvletno-mul'tifraktal'nogo podkhoda dlya otsenki struktury i svoystv malouglerodistoy stali [Material science aspects of the use of wavelet and multifractal approach for assessing of the structure and properties of low-carbon steel]. Metallofizika i noveyshiye tekhnologii [Metal Physics and Advanced Technologies]. 2011, vol. 33, no. 3, pp. 347-360. (in Russian).

18. Bolshakov V., Volchuk V. and Dubrov Yu. Fractals and properties of materials. Saarbrucken: Lambert Academic Publishing, 2016, 140 p.

19. Bolshakov V.I., Volchuk V.M. and Dubrov Yu.I. Osnovy organizacii fraktal'nogo modelirovaniya [Fundamentals of fractal modeling]. Kyiv, Ukraine : PH "Akademperiodyka" National Academy of Sciences of Ukraine, 2017, 170 p. (in Russian).

20. Blum A.S., Soto C.M., Wilson C.D., Cole J.D., Kim M., Gnade B., Chatterji A., Ochoa W.F., Lin T. W., Johnson J.E. and et al. An engineered virus as a scaffold for three-dimensional self-assembly on the nanoscale. Small, 2005, no. 1, pp. 702-706. Available at: PMID 17193509

Надійшла до редакції 13.11.2019. 